\title{
MANAJEMEN PENGELOLAAN KEUANGAN DAERAH
}

(Kajian tentang Penggunaan Keuangan Daerah dan Pengelolaannya

di Era Otonomi Daerah)

\author{
Oleh \\ Kamaluddin \\ Program Studi Administrasi Negara Universitas Muhammadiyah Sorong \\ Email : kamaluddinr67@gmail.com
}

\begin{abstract}
ABSTRAK
Pentingnya posisi keuangan daerah bagi permerintah daerah dalam membiayai berbagai kegiatan program pembangunan dalam rangka pemerataan dan laju pertumbuhan daerah yang seimbang dan sesuai dengan kemampuan keuangan daerahnya, maka paling tidak daerah tersebut harus mampu menutupi belanja rutinnya dengan pendapatan asli daerahnya disamping membiayai penyelenggaraan urusan rumah tangganya sendiri. Oleh karena itu maka penetapan alokasi serta distribusi penggunaan anggaran sesuai dengan prinsip disiplin anggaran, sehingga setiap pendapatan yang direncanakan merupakan perkiraan yang terukur secara rasional yang dapat dicapai untuk setiap sumber pendapatan, sedangkan belanja yang dianggarkan merupakan batas tertinggi pengeluaran belanja. Demikian pula dengan penganggaran pengeluaran harus didukung dengan adanya kepatian tersedianya penerimaan dalam juiniah yang cukup dan memperhatikan pentingnya pengendalian penggunaan anggaran sehingga pemerintah daerah dapat menjamin kelancaran pelaksanaan tugas pemerintahan daerah sebagai administrator pemerintahan, pembangunan dan administrator sosial kemasyarakatan maka anggaran yang tersedia diharapkan dapat dimanfaatkan secara efektif, efisien, transparan dan akuntabel.
\end{abstract}

\section{Kata Kunci : APBD, Akuntabel dan transparan}

\section{A. Pendahuluan}

Tujuan otonomi daerah sebagaimana disinyalir oleh Syamsi $(1983,47)$ adalah untuk meningkatkan daya guna dan harus guna penyelenggaraan pemerintahan di daerah terutama dalam pelaksanaan pembangunan dan pelayanan terhadap masyarakat serta untuk meningkatkan pembinaan kestabilan politik dan kesatuan bangsa. Dalam konteks seperti ini, maka penyetenggaraan otonomi daerah terutama dimaksudkan adalah untuk menunjang aspirasi perjuangan rakyat dengan mengutamakan aspek keserasian dan aspek pendemokrasian.

Salah satu syarat agar suatu daerah dapat dikatakan sebagai daerah otonomi ialah tersedianya sumber-sumber keuangan tersendiri sehingga mampu membiayai rumah tangganya sendiri. Disini nampak jelas suatu daerah yang berstatus otonom, masalah keuarigan sangatlah menentukan. Menurut Kaho $(1982,86)$ bahwa semakin banyak dana sebagai sumber pembiayaan kegiatan tugas dan fungsi. pemerintah, maka tidak kalah pentingnya faktor-faktor manajemen yang professional dalam penggunaan anggaran oleh aparatur di wilayah/daerah atau dalam unit-unit kerja instansi daerah yang diserahi tugas tersebut.

Implementasi dan ditetapkannya Undang-Undang No 32 tahun 2004 tentang Pemerintahan Daerah dan Undang-undang Nomor 33 Tahun 2004 tentang perimbangan pusat dan daerah menggantikan Undang-Undang yang pernah berlaku sebelumnya diharapkan dapat mendorong dan memfasilitasi terselenggaranya otonomi daerah, yang selama rezim orde baru berkuasa hanya menjadi retorika belaka (Kaho, 1997, 62). Untuk 
itu, maka pemerintah daerah yang selanjutnya disebut daerah otonom telah diberikan kewenangan sepenuhnya oleh pemerintah pusat untuk mengatur dan mengurus pembangunan daerah berdasarkan kepentingan dan aspirasi masyarakat. Daerah Kabupaten/Kota, tengah diperhadapkan jengan masalah peranggaran yang merupakan salah satu unsur pokok pembiayaan pembangunan dan pelayanan masyarakat. Karena itu sangat diperlukan aparat daerah yang tanggap dan sanggup menggali dan mengelola sumbersumber pendapatan daerah serta pembelanjaan sehingga tercapai apa yang telah dicita-citakan oleh masyarakat.

Disisi lain delaskan lebih lanjut oleh Prasetyo Budi $(1994,76)$ Pentingnya posisi keuangan daerah : bagi pemerintah daerah dalam membiayai berbagai kegiatan program: pembangunan dalam rangka pemerataan dan laju pertumbuhan daerah yang seimbang dan sesuai dengan kemampuan keuangan daerahnya, maka dalam penjelasan umum UndangUndang Nomor 32 Tahun 2004 tentang Pemenintahan Daerah dikemukakan bahwa :

1. Untuk menyeleniggarakan otonomi daerah yang luas, nyata dan bentanggung jawab, diperiukan kewenangan dan kemampuan menggall keuangan sendiri, yang : didukung oleh perimbangan keuangan antara pemerintah pusat dan daerah serta antara provinsi dan kabupaten/kota yang merupakan prasyarat dälãm sistem pemeñntahan daerah.

2. Dalam rangka penyelenggaraan otonomi daerah, kewenangan keuangan yang melekat pada setiap kewenangan pemerintah menjadi kewenangan daerah.

Menurut Kaho $(1997,106)$ bahwa 'Suatu daerah dapat disebut sebagai daerah otonom apabila dapat membiayai penyelenggaraan urusan rumah tangganya sendiri. Kalaupun suatu daerah otonomi belum mampu sepenuhnya membiayai urusan rumah tangganya sendiri maka paling tidak daerah tersebut harus mampu menutupi belanja rutinnya dengan pendapatan asli daerahnya. Ini merupakan satu prinsip yang harus diperhatikan dengan sungguh-sungguh". Dari berbagai gambaran pandangan ahli didepan, kiranya dapat ditegaskan bahwa terdapat dua pengertian yang dapat dirumuskan yakni:

1. Daerah Kabupaten/Kota perlu diberikan sumber-sumber pembiayaan yang cukup.

2. Daerah Kabupaten/Kota dengan kewenangan yang dimilikinya berkewajiban menggali sumber pendapatannya sendiri.

Oleh karena itu maka masalah perencanaan hendaklah dioptimalkan dan diarahkan pada perencanaan berbasis kinerja sehingga seluruh proses pengambilan keputusan dalam menetapkan arah kebijakan umum, skala prioritas dan penetapan alokasi serta distribusi penggunaan anggaran sesuai dengan prinsip disiplin anggaran, sehingga setiap pendapatan yang direncanakan merupakan perkiraan yang terukur secara rasional yang dapat dicapai untuk setiap sumber pendapatan, sedangkan belanja yang dianggarkan merupakan betas tertinggi pengeluaran belanja. Demikian pula dengan penganggaran pengeluaran hat-us didukung dengan adanya kepastian tersedianya penerimaari dalam juiniah yang cukup. dan tidak dibenarkan melaksanakan kegiatan yang tersedia atau tidak mencukupi kredit anggarannya.

Dalam konteks belanja, menurut Zamroni $(1992,101)$ pemerintah daerah hat-us mengalokasikan belanja secara adil dan merata serta secara relative dapat dinikmati oleh seluruh kelompok masyarakat i:anpä diskriminasi, khususnya dalam pemberian pelayanan umum serta diharapkan agar penggunaan ariggaran secara keseluruhan Iebih berpihak pada kepentingari masyarakat sehingga untuk dapat mengendalikan tingkat efisiensi dan efektivitas penggunaan anggaran daerah maka perencanaan anggaran perlu diperhatikan kejelasan tujuan, sasaran dan indikatjor kinerja yang ingin dicapai.

Selain dihadapkan dengan masalah anggaran untuk kebutuhan pembelanjaan daerah, Pemeriritah Kabupaten/kota dituntut untuk mampu mengoptimalkan pendapatan yang ada guna membiayai proses penyetenggaran pemerirttahari, pembangunart dart pelayanan masyarakat maka sangat dibutuhkan adanya. perencanaan anggaran yang 
teratur dan terarah dan aparat yang berwenang sehingga setiap penggunaan dana sekecil apapun dapat memberikan hasil yang optimal.

Dengan memperhatikan pentingnya pengendalian penggunaan anggaran sehingga pemerintah daerah dapat menjamin kelancaran pelaksanaan tugas pemerintah daerah sebagai administrator pemerintahan, pembangunan dan administrator sosial kemasyarakatan maka anggaran yang tersedia diharapkan dapat dimanfaatkan secara efektif, efisien, transparan dan akuntabel. Untuk itu, Pemerintah Kabupaten/Kota sedang diperhadapkan dengan tugas dan tanggung jawab penggunaan anggaran dalam setiap unit kerja dimana mereka berada terutama yang memiliki tanggung jawab langsung dalam penggunaan anggaran daerah.

\section{B. Permasalahan}

Menyimak berbagai fenomena teoritis dan realitas umum yang lihat dalam pemikiran di depan maka melalui pembahasan penulisan ini, penulis mencoba mengungkapkan secara teoritis berbagai permsalahan kajian ini dapat dirumuskan dalam permasalahan apakah Manajemen Pengelolaan Keuangan Daerah terutama Penggunaan Keuangan daerah dan Pengeloaannya di era otonomi daerah telah berlangsung sesuai ketentuan keuangan daerah yang berlaku? Untuk menelaah masalah ini melalui kajian teoritik dengan membandingkan realitas secara umum sehingga pada akhimya diharapkan dapat memberikan gambaran yang relevan atas harus kajian mi secara objektif.

\section{Kajian Teoritik}

\section{Sumber-Sumber Keuangan Daerah}

Pendapatan Asli Daerah memiliki arti yang sangat penting dalam penyelenggaraan otonomi daerah atau rumah tangga daerahnya. Posisi Pendapatan Asli Daerah sangat menentukan berbagai kemungkinan penyelenggaraan kegiatan yang akan dilaksanakan oleh daerah tersebut.

Terkait dengan pentingnya posisi keuangan daerah, Pamudji (1980, 42) mengatakan "Pemerintah daerah tidak akan melaksanakan fungsinya dengan efektif dan efesien tanpa biaya yang cukup untuk memberikan pelayanan dan pembangunan. Dari keuangan inilah yang merupakan salah satu dasar kriteria untuk mengetahui secara nyata kemampuan daerah dalam mengurus rumah tangganya sendiri.

Pendapat yang relatif sama juga dikedepankan oleh Syamsi $(1983,5)$ yang mengatakan bahwa keuangan daerah sebagai salah satu indikator untuk mengetahui kemampuan daerah dalam mengatur dan mengurus rumah tangganya sendiri.

Dan pendapat di atas terhihat bahwa untuk mengatur dan menguws rumah tangganya, daerah membutuhkan biaya atau uang. Tanpa ada biaya yang cukup, maka bukan saja tidak rnungkin bagi daerah untuk dapat menyelenggarakan tugas dan fungsi yang menjadi-tanggung jawabnya dalam mengatur dan mengurus rumah tangganya dan juga menjadikan daerah tersebut bergantung kepada pemerintah pusat sehingga kemandirian daerah tersebut kiranya perlu ditijau kembali.

Untuk dapat memiliki keuangan yang memadai dengan sendirinya daerah membutuhkan sumber keuangan yang cukup pula. Dalam hal ini daerah dapat memperoehnya melalul beberapa cara yang menurut Alfian Lains adalah:

1. Daerah dapat mengumpulkan dana dan pajak yang sudah direstui pemerintah pusat.

2. Pemerintah daerah melakukan pinjamari dan pihak ketiga, pasar uang atau bank atau melalul pemenintah pusat.

3. Ikut ambil bagian dalam pendapatan sentral yang dipungut daerah, misalnya sekian persen dan pendapatan sentral tersebut. 
4. Pemerintah daerah dapat menambah tarif pajak tertentu, misalnya pajak kekayaan atau pajak pendapatan.

5. Pemerintah daerah dadapat menerima bantuan atau subsidi dan pemenintah pusat.

Disisi lain Kennet Davey (dalam Riwu Kaho, 1997) berpendapat bahwa sumber penenimaan daerah dapat diperoleh melalui :

1. Alokasi dan pemerintah pusat

Sumber ini seringkali dinyatakan sebagam pemindahan (transfer) yang meliputi beberapa jenis :

a. Anggaran Pusat (votes) yaitu suatu penetapan bagian anggaran negara berdasarkan pada pemungutan suara dalam lembaga pembuat undang-undang vote merupakan suatu juiniah yang dialokasikan untuk tujuan tertentu yang melibatkan pemerintah daerah.

b. Bantuan pusat (grants) adalah alokasi kepada pemermntah daerah yang mandiri (denolved), menyangkut pemindahan uang tunai kepada pemerintah daerah yang mempunyai pembukuan (accounting) yang mandiri. Grants mempunyai beberapa jenis yaitu : bantuan serba guna (multi purpose), bantuan yang bertujuan tunggal per unit (unit cost), bantuan didasarkan atas presentase tertentu, bantuan pemerataan (iqualization) bantuan utnuk menutup kekurangan anggaran (deficiency grant) dan sebagainya.

c. Harus-harus pajak, bagi harus yang diterima oleh pemerintah daerah mungkin berkaitan dengan jumlah pajak yang dikumpulkan dari daerah. Harus pajak yang diserahkan mungkin dikumpulkan (di-pool) dan didistribusikan ke daerah menurut rumus-rumus tertentu, tanpa kaitan (atau sekurang-kurangnya tidak seluruhnya dikaitkan) pada asal geografisnya.

d. Pinjaman, lazimnya digunankan untuk membiayai. Perusahaan-perusahaan pembangunan (development corporation).

e. Penyertaan modal, pemerintah penerima pinjaman mutunya diharapkan untuk beroperasi secara semikomersial dan menamakan modalnya di dalam suatu kegiatanm yang self liquidating yaitu dalam suatu kegiatan yang seyogyanya akan menghasilkan laba untuk membiayai perusahaan usaha atau membayar deviden.

\section{Perpajakan Daerah}

Ada tiga cana dapat dipergunakan oleh pemermntah daerah untuk mendapatkan pajak yaitu :

a. Dengan cara pembagian harus pajak-pajak yang dipungut oleh pemenintah pusat.

b. Pemerintah Daerah dapat memungut tambahan pajak (opsen surcharge) di atas suatu pajak yang dipungut dan dikumpulkan oleh pemerintah pjisat. Para wajib pajak di wilayah (daerah) mereka pada umumnya membayar pungutan tambahan beserta pajak-pajak kepada pemerintah pusat, yang pada gilirannya membayarkan pendapatan opsen terseut kepada Pemerintah Daerah.

c. Dan. pungutan-pungutan yang dikumpulkan dan ditahan oleh pemerintah daerah.

\section{Retribusi}

Restribusi adalah pungutan yang dibayar langsung oleh mereka yang menikmati suatu pelayanan dan biasanya dimaksudkan untuk menutup seluruh atau sebagian dart biaya pelayanannya. Contohnya : sewa atas rumah milik daerah, pungutan irigasi, karcis masuk kolam renang dan masih banyak lagi lainnya. 
4. Pinjaman

Pinjaman oleh pemerintah daerah dapat berupa penyaluran keuangan dart pemerintah pusat dan juga peminjaman dari sumber lainnya termasuk badah-badan internasional dana-dana kredit yang dikelola oleh pemerintah pusat, bank-bank komersial lembaga-lembaga keuangan yang lain atau dapat juga penanaman modal swasta.

5. Perisahaan (Badan Usaha)

Pemerintah daerah dapat juga memperoleh penerimaan dan pengoperasian perusahaan-perusahaan komersial untuk pengolahan produksi, sebagai swasta sumber pendapatan bersih dasarnya adalah semacam pungutan restribusi akan tercapal pungutari itu dengan maksud mendapatkan laba uuntuk membiayai usaha-usaha lainnya, bukan sekedar mengoperasikan perusahaan-perusahaan sendiri.

Dari berbagai pemikiran tentang sumber penerimaan daerah seperti terlihat didepan dapat dikatakan bahwa sumber-sumber tersebut dapat dikiasifikasikan menjadi dua yakni : penerimaan daerah yang berasal dari pemerintah pusat, dan penerimaan daerah yang berasal dari daerah itu sendiri atau pendapatan asli daerah.

Pajak dan restribusi daerah yang merupakan komponen sumber pendapatan asli daerah senantiasa diharapkan oleh setiap daerah mengalami peningkatan dari tahun ke tahun sebagai tambahan dana bagi daearah tersebut untuk dapat dipergunakan membiayai berbagai keperluan yang telah ditantukan oleh daerah, termasuk membiayai kegiatan rutinnya.

Sehubungan dengan itu maka hal-hal yang menentukan dan perlu mendapat perhatian menurut Davey (1988) yaitu :

1. Hubungan antara alokasi tanggung jawab fungsional dengan pelimpahan sumbersumber penenmaan yang juga mencakup perimbangan antara tugas-tugas dan sumber dayanya.

2. Tingkat kewenangan regional yang disiapkan dalam pengelolaan masing-masing tugas dan sumber daya.

Untuk mengelola Pendapatan Asli Daerah, pemerintah daerah memerlukan suatu lembaga atau organisasi pemerintah yang bertanggung jawab dalam pengelolaannya sehingga berbagai sumber pendapatan terutama yan berasal dan elemeni sumber-sumber pemdapatan asli daerah yang digali dapat dikembangkan secara optimal. Lembaga atau organisasi dimaksud adalah Dinas Pendapatan Daerah (Dispenda) yang di tingkat propinsi disebut dengan DISPENDA Propinsi dan di tingkat Kabupaten atau kotamadya disebut DISPENDA Kabupaten/Kota.

Untuk mencapai tujuan organisasi tersebut maka misi dan mandat organisasi merupakan komponen yang penting dimana keduanya saling terkait satu sama lainnya. Untuk meningkatkan penerimaan pendapatan kemampuan keuangan daerah dalam membiayai penyelenggaraan pemerintah dan pembangunan daerah. Dengan demikian Dispenda adalah unsur pelaksana teknis pemerintah daerah di bidang pendapatan yang berada dan bertanggung jawab kepada Bupati/Bupati. Sedangkan mandatnya terkait dengan tugas dan fungsi yang dimiliki yaitu selain menggahi sumber-sumber keuangan daerah yang telah dihimpahkan kepada dinas tersebut, juga sebagai kordinator dan dinas-dinas dan lembaga-lembaga lainnya yang terkait dalam bidang pungutan daerah. 
Otonomi daerah yang diberikan kepada pemerintah daerah telah menjadi tekad pemerintah pusat. Dalam angka penyelenggaraan otonomi daerah maka pemerintah daerah harus siap menerima beban dan tanggung jawab urusan-urusan yang diserahkan untuk dilaksanakan sesuai dengan tuntutan masyarakat setempat termasuk tanggung jawab urusan-rusan yang diserahkan untuk dilaksanakan sesuai dengan tuntutan masyarakat setempat termasuk tanggung jawab untuk mengatur sumber daya dan dana yang ada sehinggah daerah benar-benar siap baik sumber daya manusia maupun sumber keuangan untuk pembiayaan penyelenggaraannya.

Berdasarkan kenyataan tersebut maka Dinas Pendapatan Daerah dituntut untuk harus dapat meningkatkan kinerjanya, karena jika tidak maka kegagalan penyelenggaraan otonomi daerah tidak dapat terelakkan, minimal akan terlihat kesan rendahnya kualitas pelayanan kepada masyarakat. Untuk itu dalam mengukur kinerja organisasi publik haruskah dikaitkan dengan para stakeholders disamping produktifitas yang dicapai.

Karena itu, sening terjadi kesulitan dalam pengkuran kinerja organisasi publik yang menurut Dwiyanto (1995:1) sebagiannya muncul karena tujuan dan misi organisasi publik sering kah bukan hanya sangat kabur dan tetapi juga bersifat multi dimensional. Organisasi public memiliki stakeholders yang jauh lebih banyak dan kompleks ketimbang organisasi swasta. Stakeholders dan organisasi publik sering kali memiliki kepentingan yang berbenturan satu dengan yang lainnya. Akibatnya, ukuran kinerja organisasi publik dimata para stakeholder juga menjadi berbeda.

Lanvine (1990) masih dalam Dwiyanto $(1995,6)$ mengemukakan tiga konsep dalam mengukur kinerja organisasi publik yaitu Responsivitas (responsiveness) menunjuk pada keselarasan antara program kegiatan pelayanan yang dberikan oleh organisasi publik dengan kebutuhan dan keinginan masyarakat. Responsibilitas (responsibility) menjelaskan sejauhmana pelaksanaan kegiatan organisasi public itu di laksanakan sesuai prinsip-prinsip administrasi dan peraturan dan kebijaksanaan organisasi maka kinerja dinilai semakin baik. Dan Akuntabilitas menunjukan pada seberapa besar kegiatan dan kegiatan organisasi publik tunduk pada para pejabat politik yang dipihh oleh rakyat (wakil-wakil rakyat).

Dalam konsep ini kinerja organisasi publik dinilai baik apabila seluruhnya atau tidaknya sebagian besar besar kegiatan didasarkan pada upaya untuk memenuhi harapan dan keinginan para wakil rakyat. Semakin banyak tindak lanjut organisasi atas harapan dan aspirasi pejabat politik maka kinerja organisasi publik itu dinilai semakin baik.

Kinerja, pada pririsipnya berhubungan dengan : Pertama, aspek-aspek input atau sumber-sumber dayanya (resources), antara lain seperti (1) pegawai (SDM); (2) anggaran; (3) sarana dan prasarana; (4) informasi; dan (5) budaya organisasi.

Kedua berkaitan dengan proses manajemen (1) perencanaan; (2) pengorganisasian; (3) pelaksanaan; (4) penganggaran; (5) pengawasan; (6) evaluasi.

Di samping faktor internal tersebut, perlu juga diperhatikan aspek-aspek lingkungan eksternal yang secara langsung maupun tidak ikut mempengaruhi kinerja, seperti kondisi politik, ekonomi, sosial-budaya, dan teknologi, juga pihak-pihak yang terkait dengan penyediaan input, misalnya wajib pajak, para pembuat kebijakan, dan sebagainya.

Setiap aspek di atas memiliki potensi yang sama untuk muncul sebagai faktor dominan yang mempengaruhi kinerja organisasi, baik yang berpengaruh secara positif maupun negatif. Selanjutnya untuk mengidentifikasi isu-isu strategis yang dihadapi oleh organisasi berdasarkan mandat dan misi organisasi serta faktor-faktor internal dan faktor-faktor ekstennal yang dihadapi oleh organisasi, kita memerlukan suatu 
manajemen strategis, untuk merumuskan strategi dalam rangka mengelola isu-isu strategis tersebut.

\section{Standar Analisa Belanja Daerah}

Anggaran daerah pada hakekatnya merupakan salah satu alat untuk meningkatkan pelayanan publik dan kesehjateraan masyarakat sesuai dengan tujuan otonomi daerah yang luas, nyata dan bertanggung jawab. Dengan demikian APBD harus benar-benar dapat mencerminkan kebutuhan masyarakat dengan memperhatikan potensi dan keanekaragaman daerah.

Standar analisa belanja (SAB) merupakan salah satu komponen masyarakat yang harus dikembangkan sebagai dasar pengukuran kinerja kuangan dalam penyusunan APBD dengan pendekatan kinerja. SAB adalah standar untuk menganalisis anggaran belanja yang digunakan dalam suatu program atau kegiatan untuk menghasilkan tingkat pelayanan tertentu sesuai dengan kebutuhan masyarakat. SAB digunakan untuk menilai kewajaran beban kerja dan biaya setiap program atau kegiatan yang akan digunakan oleh unit kerja selama satu tahun anggaran. Penilaian terhadap usulan anggaran belanja dikaitkan dengan tingkat pelayanan yang akan dicapal melalui program atau kegiatan. (anonim, 1985)

Dalam rangka menyiapkan rancangan APBD, SAB merupakan standar atau pedoman yang bermanfaat untuk menilai kewajaran atas beban kerja dan biaya terhadap suatu kegiatan yang direncanakan oleh setiap unit kerja. SAB dalam hal mi digunakan untuk menilai dan menentukan rencana program, kegiatan belanja yang paling efektif dalam upaya pencapaian kinerja. Penilaian kewajaran berdasarkan SAB berkaitan dengan kewajaran biaya suatu program atau kegiatan yang dinilai berdasarkan hubungan antara rencana alokasi biaya dengan tingkat pencapaian kinerja program atau kegiatan yang bersangkutan. (anonim, 1985).

\section{Perencanaan Strategik dan Perencanaan Anggaran Daerah}

Perencanaan stratejik adalah suatu proses. Sebagai suatu proses, perencanaan mi menentukan apa yang dikehendaki suatu organisasi dimasa yang akan datang dan bagaimana upaya mencapainya. Sedemikian besamya peranan perencanaan stratejik tersebut sehingga ia tidak dapat didelegasikan. (Bastian Indra, 2006)

Perencanaan stratejik merupakan rencana bertindak tentang bagaimana suatu organisasi hendak mencapai tujuan yang diinginkan. Perencanaan mi mucul sebagai reaksi terhadap semakin banyaknya perubahan strukural dan ekonomi, regional dan global, serta meluasnya ketidakpastian, kompleksitas dan situasi lingkungan ekstemal. Dengan demikian, perencanaan ini harus diorentasikan pada lingkungan eksternal. Posisi dan perencanaan stratejik lebih kepada perencanaan jangka pendek ke menengah dan bukan perencanaan jangka panjang.

Perencanaan stratejik ini tidak sama dengan sistem perencanaan, penyusunan program dan penganggaraan, namun demikian perecanaan stratejik berkaitan derigan proses penganggaraan, dalam arti menjelaskan tujuan dan sasaran yang dikehendaki. ini dimulai dengan terlebih dahulu membuat kebijakan stratejik tentangvisi. (Bastian Indra, 2006)

Perubahpn lingkungan yang terjadi, baik ditingkat global, nasional maupun 3aerah perlu diantisipai dan dihadapi daerah degan sejuiniah langkah dan kebhjakan baru yang renponsive terhadap perubahan yang terjadi. Dalani hat ini, peranan perencanaan stratejik sangat penting. Oleh karena itu, perencanaan stratejik dapat 
disebut sebagai metode yang berurusan dengan kompleksitas lingkungan yang sering kali erat hubungannya dengan kepentingan organisasi.

Proses perencanaan dan penganggaran daerah biasanya dipengaruhi oleh lingkungan yang terdiri atas faktor internal dan eksternal. Strategi dalam méwujudkan perencanaan dan penganggaran ini pun mengikuti permasalahan yang terjadi yaitu strategi Internal dan strategi Eksternal. Dalam proses mi pemermntah daerah mémerlukan integrasi antara keahlian sumber daya manusia dan sumber daya lainnya untuk menjawab tuntutan perkembangan lingkungan. strategis baik yang terjadi secara Internal màupun Eksternal.

Didalam penjelasan atas PP No 20 / 2004 tentang rencana kerja pemerintah, untuk mencapai hasil yang dimaksudkan sistem penganggaran dan perencanaan harus menciptakan lingkungan yang mendukung (enebling enviroment) dengan karakteristik:

a. Mengkaitkan perencanaan dan penganggaran dengan pengambilan keputusan untuk memastikan perencanaan kebijakan, program dan kegiatan telah mempertimbangkan kendala anggaran dengan memastikan bahwa biaya sesuai dengan harus yang diharapkan.

b. Memberikan media/forum bagi alternative kebijakan untuk berkompetisi satu sama lain. Hal ini sangat penting bagi tumbuhnya dukungan pada tahap pelaksanaannya nanti.

c. Meningkatkan kapasitas dan kesediaan untuk melakukan penyesuaian priontas kembali alokasi sumber daya.

\section{Kesimpulan.}

Berdasarkan harus dan pembahasan teoritis, dapat disimpulkan bahwa penggunaan administrasi keuangan daerah pada kantor Sekretariat Kabupaten/Kota terutama dalam telah berlangsung sesuai dengan asas analisa umum dan analisa belanja keuangan daerah. Dengan demikian dapatlah ditegaskan bahwa keuangan daerah yang selama ini dikelolah oleh aparatur yang bertanggungjawab dalam bidang keuangan telah berlangsung sesuai yang diharapkan atau sejalan dengan ketentuan-ketentuan administrasi keuangan yang berlaku atau manajemen keuangan daerah yang dikelola telah berlangsung secara efektif, efisien, transparan dan akuntabel.

Selain itu dukungan ketaatan aparatur pemerintah yang bertanggungjawab dalam bidang keuangan di tingkungan Sekretariat Daerah telah berjalan baik, pasalnya para pegawal seriantisa menaati pekerjaan sesuai dengan ketentuan waktu yang berlaku. Begitupun para pegawai menunjukan ketaatan dalam melaksanakan tugas dan tanggungjawabnya dalam penggunaan administrasi keuangan daerah sesuai ketentuan asas analisa umum dan analisa belanja keuangan daerah. Begitu juga mutu dan hasil pekerjaan yang dicapai pegawal tersebut sudah berjalan dengan positif, sebab harus pekerjaan para pegawai kualitasnya sesuai dengan harapan. Dimana kualitas hasil pekerjaan mengalami peningkatan yang signifikan karena mereka memiliki kemampuan yang memadai.

DAFTAR PUSTAKA

Anonim, Research Methodology, a step by guide for beginness, 1985

Bastian Indra, Kinerfa Kebqakan Pajak Daerah Tingkat II di Indonesia, PPSUGM, Yogyakarta, 2006

Dwiyanto Agus, Dwiyanto Agus, Penilaian Kinerja Organisasi Pelayanan Publik, Makalah disampakan pada seminar sehari Kinerja Organisasi di sector Publik, kebijakan dan Penerapannya, Jurusan II. Adm. Negara, FISIPOL UGM, Yokyakarta,1995 
Lains, Alfian, 1985, Pendapatan Daerah dalam Ekonomi Orde Baru, Prisma Nomor 4, Jakarta, 1999.

Pamudji, S., Pembinaan Perkotaan di Indonesia, Ikhtisar, Jakarta, 1980.

Prasetyo S. Budi, 1994, K'ne,a Kebyakan Pajak Daerah Tingkat lid/Indonesia, PPS-UGM, Yogyakarta.

Riwu, Kaho Yosep, Anal/se Hubungan Pemerintah Pusat dan Daerah di Indonesia, Bina Aksara, Jakarta, 1982.-

--Prospek Otonomi Daerah di Negara Republik Indonesia, PT. Raja Grafindo Persadà, Jakarta, 1997.

Syamsi, Ibnu, 1983, Administrasi Materill Pemerintahan Daerah, Bina Aksara, Jakarta.

Zamroni, 1992, Pengantar Pengembangari Teori Sos/al, PT. Tiara Wacana, Yogyakarta. 